\title{
Dr Alec Sand, F.R.S.
}

In the sad death of Dr Alec Sand in July 1945, at the age of 43, we have lost one of the ablest comparative physiologists in the country.

Born in Warsaw, he was two years old when his parents brought him to London. As a youth he was determined to get a University training, but his funds would not permit him to do so in this country. So, with characteristic drive, he went to Canada and worked his way through College in British Columbia, taking a degree in Science and Agriculture. This enabled him to take a junior post in bacteriology in the Agricultural Faculty of McGill University. He took up research on soil micro-organisms and on this obtained his $\mathrm{Ph} . \mathrm{D}$. degree. This was the origin of his first published paper, on Azotobacter.

While at McGill, Sand came under the influence of Prof. Lancelot Hogben who had begun at that University to develop his school of comparative physiology. This was a turning point in Sand's career, and when Hogben went to the University of Cape Town, he soon joined him on his staff. It was here that Sand's work turned towards comparative physiology. The rich fauna which he now saw and the varied adaptations to the conditions of existence strongly appealed to him. His work on the respiratory mechanism of crabs, scorpions and Sabellid worms was done at this time. From Hogben he derived a great interest in colour response in animals and he did excellent work on the pigmentary effector system of the Chameleon.

In 1933 Sand left South Africa and went to Cambridge to work with Prof. J. Gray in his studies of locomotion in Vertebrates. The ideas and techniques he then developed bore fruit when soon afterwards he was appointed Physiologist at the Marine Biological Laboratory, Plymouth. It was there that partly by himself and partly with the able co-operation of $\mathrm{Dr} \mathrm{O}$. Lowenstein he did his outstanding work on the sense organs of fishes. It is to this work more than to any other that we owe' our knowledge of the excitatory mechanism of the lateral line system and labyrinth in fishes. His further unexpected demonstration that the ampullae of Lorenzini function as temperature receptors is a masterpiece of careful observation and experimental design combined with insight and shrewdness of interpretation. It was these characteristics, which come out so clearly in this work, that were the memorable features of the man himself. Visitors to the Plymouth Laboratory will remember not only his brilliance and ingenuity, but also his kindly and helpful criticism, qualities which are not always linked in the same personality as they were in his. His fine work in biology was recognized by his election to the Royal Society in 1945 .

Early in the war he volunteered for the Navy. He was selected for work on radiolocation, and commissioned as Lieutenant. He served in the north of 
Scotland, in England and in a cruiser in the Indian Ocean. There his work scored some signal successes. He was later on a monitor at the invasion of Sicily, where his ship sustained heavy casualties from a bomb. After this he was seconded to the Medical Research Council's Laboratory for work on naval problems. With the conclusion of the war we all hoped soon to see him return to Plymouth. As it is, we have lost one of the ablest biologists at a time when he is most needed, and at a time when his full power of mind had just developed.

Alec Sand was married and during the war his wife and two boys went to South Africa. We can only give them our sympathy for their great loss.

C.F.A.P. 